\title{
Aging Methods-An Evaluation of Their Influence on Bond Strength
}

\author{
Gabriela Simões Teixeira ${ }^{1} \quad$ Gabriel Kalil Rocha Pereira ${ }^{1} \quad$ Alexandre Henrique Susin ${ }^{1}$ \\ ${ }^{1}$ Department of Restorative Dentistry, Federal University of Santa \\ Address for correspondence Gabriela Simões Teixeira, DDS, MSD, \\ PhD, Federal University of Santa Maria, Roraima Avenue, 1000, \\ 26F Building, Room 2248, Camobi, Santa Maria, Rio Grande do Sul \\ 97105-900, Brazil (e-mail: gsimoesteixeira@gmail.com).
}

Eur J Dent 2021;15:448-453

\begin{abstract}
Keywords

- artificial aging

- interface degradation

- hydrolysis

- universal adhesive
\end{abstract}

Objectives To evaluate the effect of different artificial aging methods on the bond strength of a resin composite associated with a universal adhesive (Scotchbond Universal) used under two etching approaches (self-etch [SE] or etch-and-rinse [ER]) to enamel and dentin substrates.

Materials and Methods A total of 96 noncarious human third molars were prepared and randomly divided according to three factors $(n=6)$ : substrate (enamel and dentin), adhesive approach (SE and ER), and aging method (water storage for 24 hours, 6 months, or 1 year; subjected to $10,000,20,000$, or 30,000 thermal cycles; and sodium hypochlorite $[\mathrm{NaOCl}]$ storage for 1 or 5 hours).

Statistical Analysis Microshear bond strength tests were conducted, and the collected data ( $\mathrm{MPa}$ ) were subjected to three-way analysis of variance (ANOVA) with post hoc Bonferroni tests $(p<0.05)$ and Weibull analysis. The failure pattern was also evaluated.

Results Three-way ANOVA revealed that the factors "substrate" $(p=0.00)$ and "aging method" ( $p=0.00)$ had a significant effect on the bond strength, but the factor "adhesive approach" did not $(p=0.84)$. The bond strength in the enamel group for the SE approach was negatively affected under 20,000 and 30,000 thermal cycles. Weibull presented the highest $m$ in the $\mathrm{NaOCl}$ storage for the 5 hours group to enamel using the $\mathrm{SE}$ and to dentin using ER approaches. Adhesive/mixed failures were predominant for all groups.

Conclusion Thermocycling aging (20,000 and 30,000 cycles) significantly reduced the bond strength to enamel using the SE approach. On the contrary, storage with the $\mathrm{NaOCl}$ method proved to increase bond strength under the evaluated conditions.

\section{Introduction}

Human enamel and dentin tissues present clear differences regarding their micromorphology and the balance of organic and inorganic contents, which consequently result in different performance of adhesive systems onto such tissues. ${ }^{1,2}$ The interface between the resin composite and the

published online

January 28, 2021
DOI https://doi.org/

$10.1055 / \mathrm{s}-0040-1721906$

ISSN 1305-7456. cavity walls is the most critical region in bonded restorations. Unprotected collagen depleted fibrils ${ }^{3}$ and chemical hydrolysis of the ester bonds are considered the main reasons for hybrid layer degradation. These processes occur concomitantly and definitively contribute to reducing bond strength over time. ${ }^{4}$ (c) 2021. European Journal of Dentistry.

This is an open access article published by Thieme under the terms of the Creative Commons Attribution-NonDerivative-NonCommercial-License, permitting copying and reproduction so long as the original work is given appropriate credit. Contents may not be used for commercial purposes, or adapted, remixed, transformed or built upon. (https://creativecommons.org/licenses/by-nc-nd/4.0/) Thieme Medical and Scientific Publishers Pvt. Ltd., A-12, 2nd Floor, Sector 2, Noida-201301 UP, India 
The newest universal adhesives enable dentists to apply the adhesive following a self-etch (SE), etch-and-rinse (ER), or an alternative selective enamel etching approach. The latter is an association of an ER approach onto enamel and the SE approach to dentin. ${ }^{5}$ Universal adhesives in the literature are described as a single-bottle and no-mix adhesive system which performs satisfactorily using any adhesion strategy and to any substrate considering the restorative dentistry scenario (dental tissues, as well as different direct or indirect restorative materials). ${ }^{6}$

In vitro aging methods have been considered a must in any laboratorial adhesion study, as they may help the researchers better understand and predict the performance of adhesives systems concerning bonding degradation. ${ }^{7}$ Thus, microshear bond strength testing ( $\mu \mathrm{SBS}$ ) values may represent valuable information concerning the influence of different aging methods on bond strength. Different aging methods such as storage in water, ${ }^{4}$ thermocycling, ${ }^{8}$ and storage in sodium hypochlorite $(\mathrm{NaOCl})$ solution, ${ }^{9}$ as well as associations between them ${ }^{10}$ have been applied to predict the clinical behavior and its repercussions on the bonding efficacy in the long term of the adhesive systems. ${ }^{11,12}$ Despite these studies, comparisons and guidance to which is the best in vitro aging method for these objectives are lacking.

Aging by storage in water commonly uses immersion of the samples in distilled water at $37^{\circ} \mathrm{C}$ from 3 to 12 months $^{13}$ to partially simulate the oral environment conditions. Moreover, 10,000 to 30,000 cycles $^{8}$ are used in the thermocycling method, in which hot and cold water intermittently can stimulate the hydrolysis of unprotected collagen fibrils by repetitive contraction/expansion stress, resulting in gap propagation along the adhesive interface, thereby allowing water and pathogenic oral fluid penetration. ${ }^{14,15}$ The storage method in $10 \%$ of $\mathrm{NaOCl}$ solution from 1 to 5 hours $^{10,15}$ uses the nonspecific proteolytic effect properties of the hypochlorite to degrade the organic resin and tooth interface components (as unprotected collagen fibrils) to simulate the aging effect.

Thus, based on the limited information in the current literature comparing distinct aging methods and its effect on enamel and dentin, the present study aimed to evaluate and compare the effect of different artificial aging methods on the bond strength of composite resin restorations associated with a universal adhesive under $\mu$ SBS. The null hypothesis is there would not be differences regarding the different aging methods in promoting interfacial bond degradation.

\section{Materials and Methods}

\section{Study Design}

This in vitro study was approved by the local ethics committee in research (protocol number 2.054.447, CAAE 67687417.9.0000.5346). A total of 96 noncarious and crack-free human third molars were collected from an institutional teeth bank up to 3 months after extraction by clinical indications. The teeth were stored in $0.5 \%$ chloramine- $\mathrm{T}$ at $37^{\circ} \mathrm{C}$ during 7 days to disinfection, since it has no influence on bond strength. ${ }^{16}$

\section{Specimen Preparation}

The roots were cut off and the crowns were mesiodistally sectioned using a low-speed water cooled diamond saw in a cutting machine (Labcut 1010, ExtecInc, Enfield, Connecticut, United States). The sections were embedded in PVC rings with self-curing acrylic resin (JET, Classico Art Od, São Paulo, Brazil). The thickness of smear layer was standardized by using a 600-grit silicon carbide paper for 1 minute in a circular mechanical polishing machine (EcoMet 250; Buehler, Lake Bluff, Illinois, United States) under water irrigation. ${ }^{17}$

Approved samples were then randomized and divided into 32 groups $(n=6)$ according to three factors: "adhesive approach" (2): ER and SE; "substrate" (2): enamel and dentin; and "aging methods" (8): water storage at $37^{\circ} \mathrm{C}$ for 24 hours (W24h as control group), 6 (W6m), 12 months (W12m); thermocycling in 10,000 (T10,000), 20,000 (T20,000), or $30,000(\mathrm{~T} 30,000)$ cycles; and $10 \% \mathrm{NaOCl}$ storage for 1 (SH1h) and 5 hours (SH5h) as described in - Table 1.

\section{Bonding and Restoration Procedures}

A universal adhesive (Scotchbond Universal-3M ESPE Dental Products; St. Paul, Minnesota, United States) using SE and ER approaches was applied according to the manufacturer's instructions to enamel and dentin (-Table 2). Next, three starch tubes (Renata; PastificioSelmi, Londrina, Parana, Brazil) of $1 \mathrm{~mm}$ height and $0.96 \mathrm{~mm}$ internal diameter hole were positioned on mesial, central, and distal thirds over each substrate before adhesive photocuring, as is described by Tedesco et al (2013)..$^{18} \mathrm{~A}$ light-emitting diode (Emitter DShuster Eq. Od. Ltd, Santa Maria, Brazil) with $900 \mathrm{~mW} / \mathrm{cm}^{2}$ light output was used to light activate the adhesive for 10 seconds, and then, a resin composite (Filtek Z350 XT shade A2; 3M ESPE Dental Products) was used to fill in the starch tubes, followed by light activation using the same light unit for 20 seconds.

Table 1 Experimental design

\begin{tabular}{|c|c|c|c|c|c|c|c|c|c|}
\hline \multicolumn{10}{|l|}{ Study factors } \\
\hline \multirow{2}{*}{$\begin{array}{l}\text { Adhesive } \\
\text { approach }\end{array}$} & \multirow[t]{2}{*}{ Substrate } & \multicolumn{8}{|c|}{ Aging method } \\
\hline & & W24h & W6 m & W12 m & $\mathrm{T} 10,000$ & $\mathrm{~T} 20,000$ & T30,000 & SH1 h & SH5 h \\
\hline \multirow[t]{2}{*}{ Etch-and-rinse } & Dentin & \multirow{4}{*}{\multicolumn{3}{|c|}{$\begin{array}{l}\text { Samples prepared and immediately } \\
\text { stored in distilled water at } 37^{\circ} \mathrm{C} \text { for } \\
24 \mathrm{~h}, 6 \text { mo, or } 12 \text { mo before testing } \\
\text { For the longer periods ( } 6 \text { and } 12 \mathrm{mo} \text { ), } \\
\text { water was changed weekly }\end{array}$}} & \multirow{4}{*}{\multicolumn{3}{|c|}{$\begin{array}{l}\text { Samples thermocycled } 10,000 ; \\
20,000 \text {; or } 30,000 \text { times at } 5-55^{\circ} \mathrm{C} \\
\text { for } 30 \text { s each batch, } 5 \text { s of transfer } \\
\text { time, before testing }\end{array}$}} & \multirow{4}{*}{\multicolumn{2}{|c|}{$\begin{array}{l}\text { Samples kept immersed } \\
\text { in } 10 \% \mathrm{NaOCl} \text { solution at } \\
\text { room temperature for } \\
1 \text { or } 5 \mathrm{~h} \text {, before testing }\end{array}$}} \\
\hline & Enamel & & & & & & & & \\
\hline \multirow[t]{2}{*}{ Self-etch } & Dentin & & & & & & & & \\
\hline & Enamel & & & & & & & & \\
\hline
\end{tabular}


Table 2 Materials used in this study-application procedure

\begin{tabular}{|l|l|l|l|l|}
\hline Material & Manufacturer & Composition & Usage approach \\
\cline { 3 - 4 } & & SE approach & Etch-and-rinse approach \\
\hline $\begin{array}{l}\text { 37\% phosphoric } \\
\text { acid }\end{array}$ & $\begin{array}{l}\text { Condac 37-FGM, } \\
\text { Joinville, SC, Brazil }\end{array}$ & $\begin{array}{l}\text { 37\% phosphoric acid, filler, } \\
\text { pigment and deionized water }\end{array}$ & - & $\begin{array}{l}\text { 1. Apply phosphoric acid gel } \\
\text { for 20 s } \\
\text { 2. Rinse with water } \\
\text { 3. Dry with cotton pellets }\end{array}$ \\
\hline $\begin{array}{l}\text { Adhesive } \\
\text { system }\end{array}$ & $\begin{array}{l}\text { Scotchbond } \\
\text { Universal-3M ESPE } \\
\text { Dental Products, } \\
\text { St. Paul, Minnesota, } \\
\text { United States }\end{array}$ & $\begin{array}{l}\text { 2-HEMA, 10-MDP, phosphate } \\
\text { monomer, dimethacrylate resins, } \\
\text { methacrylate-modified, } \\
\text { polyalkenoic acid copolymer, filler, } \\
\text { ethanol, water, initiators, silane }\end{array}$ & $\begin{array}{l}\text { 1. Actively apply the } \\
\text { adhesive to the prepared } \\
\text { tooth for 20 s } \\
\text { 2. Gently air-dry for 5 s } \\
\text { 3. Light activated for 10s }\end{array}$ & $\begin{array}{l}\text { 1. Steps 1 to 3 of the above cell } \\
\text { 2. Apply adhesives as } \\
\text { 3. Light activated for 10 s }\end{array}$ \\
\hline $\begin{array}{l}\text { Resin } \\
\text { composite }\end{array}$ & $\begin{array}{l}\text { Filtek Z350-3M } \\
\text { ESPE Dental } \\
\text { Products }\end{array}$ & $\begin{array}{l}\text { Silica 20 nm, zirconia 4-11 nm, } \\
\text { Bis-GMA, Bis-EMA, UDMA, } \\
\text { TEGDMA }\end{array}$ & $\begin{array}{l}\text { 1. Apply two increments of resin composite } \\
\text { 2. Light activated for 20 s after each increment }\end{array}$ \\
\hline
\end{tabular}

Abbreviations: 2-HEMA, 2-hydroxyethyl methacrylate; 10-MDP, 10-methacryloyloxydecyl dihydrogen phosphate; Bis-EMA, bisphenol A polyethylene glycol dimethacrylate; Bis-GMA, bisphenol A glycidyl dimethacrylate; SE, self-etch; TEGDMA, triethylene glycol dimethacrylate; UDMA, urethane dimethacrylate.

Finally, the samples were stored for 24 hours in distilled water at $37^{\circ} \mathrm{C}$, and the starch matrix was removed with airwater spray. The enamel/resin and dentin/resin interfaces were examined using a stereomicroscope at $\times 10$ magnification (Discovery V20, Zeiss; Oberkochen, Germany), and specimens which presented interfacial defects such as bubbles or voids were substituted.

\section{Microshear Bond Strength Test}

After the aging process, the $\mu \mathrm{SBS}$ tests were executed using the wire loop technique ${ }^{19}$ with a $0.2-\mathrm{mm}$ stainless steel wire attached to a specific device in a universal testing machine (EMIC DL 1000; Instron, S.J. Pinhais, Brazil). Shear load was applied at a crosshead speed of $1.0 \mathrm{~mm} / \mathrm{min}$ with cell of $1 \mathrm{kN}$ until failure of the bonded restoration. Caution was taken for the parallelism between the wire, the load cell, and the adhesive-resin interface, as well as to make the load application as close as possible to the bond interface.

\section{Failure Analysis}

The failed specimens were examined by a trained and blinded single operator in a stereomicroscope (Discovery V20, Zeiss) at $\times 40$ magnification to determine the failure mode, which was categorized as adhesive/mixed, cohesive in enamel/dentin, or cohesive in resin composite.

\section{Statistical Analysis}

All statistical tests were performed at OriginPro 2015 (OriginLab Co.; Northampton, Massachusetts, United States) with a significance level of $5 \%$. The bond strength result in $\mathrm{MPa}$ was considered as the measuring unit for each sample. Thus, after assuring parametric data distribution (Shapiro-Wilk's test), the three-way analysis of variance (ANOVA) was used for the factors "adhesive approach," "substrate," and "aging method." Multiple comparisons were tested with post hoc Bonferroni. In addition, a Weibull statistical analysis using the maximum likelihood method was run to obtain the shape (Weibull modulus-m) parameter for each condition. ${ }^{20,21}$ The Weibull modulus is a measure of the variability of the results, ${ }^{22}$ where a low value of $m$ indicates a wide scatter of results, while a high value of $m$ indicates a close grouping of fracture stress values. Thus, the value of $m$ can be interpreted as giving an indication of the dependability of the material..$^{23}$

Statistical differences of Weibull parameters were detected by maximum likelihood estimation (absence of overlap of $95 \%$ confidence intervals).

\section{Results}

The $\mu \mathrm{SBS}$ expressed in MPa and standard deviations are summarized in - Table 3. Three-way ANOVA for repeated measures revealed that the factors "substrate" $(p=0.00)$ and "aging method" ( $p=0.00$ ) had significant effects on bond strength. Meanwhile, the factor "adhesive approach" (SE or ER) did not $(p=0.84)$. The triple interaction (adhesive substrate aging method) also did not present a statistically significant effect $(p=0.86)$. The "in pairs" interactions revealed a significant effect on the comparisons of "substrate" $\times$ "aging method" $(p=0.01)$, and the "adhesive approach" $\times$ "aging method" $(p=0.00)$.

The results showed that the different aging methods promoted distinct results for each approach of adhesive and substrates. The bond strength in the enamel group using the SE approach under 20,000 (7.00 MPa) and 30,000 (8.26 MPa) thermal cycles was negatively affected in comparison with the control group (W24h) (12.02 MPa). Six months of water storage using the SE adhesive approach for both substrates affected the bond strength less using 20,000 thermal cycles. The opposite happened when the ER approach was used, in which water storage for 6 months affected the bond strength more than the 20,000 thermal cycles and storage in hypochlorite regardless of the time.

- Table 4 summarizes the Weibull distribution presenting the highest $m$ in the SH5h group for ER (5.42) to dentin, while the highest $m$ to enamel was presented for the W24h group (5.48), also using the ER approach. The probability plot regarding failure over time for enamel and dentin is presented separately for each aging method ( - Fig. 1A-C). It was noticed that the $\mathrm{NaOCl}$ aging presented more predictable 
Table 3 Microshear bond strength, standard deviation, and statistical significance

\begin{tabular}{|c|c|c|c|c|c|c|c|c|c|}
\hline $\begin{array}{l}\text { Adhesive } \\
\text { approach }\end{array}$ & Substrate & W24 h & W6 m & W12 m & $\mathrm{T} 10,000$ & $\mathrm{~T} 20,000$ & T30,000 & SH1 h & SH5 h \\
\hline \multirow[t]{2}{*}{ SE } & $E$ & $\begin{array}{l}12.02 \\
(3.85)^{\mathrm{ab}}\end{array}$ & $\begin{array}{l}12.06 \\
(3.52)^{\mathrm{ab}}\end{array}$ & $\begin{array}{l}10.32 \\
(5.23)^{\mathrm{ab}}\end{array}$ & $\begin{array}{l}9.70 \\
(3.73)^{\mathrm{bc}}\end{array}$ & $\begin{array}{l}7.00 \\
(3.74)^{c}\end{array}$ & $\begin{array}{l}8.26 \\
(3.38)^{c}\end{array}$ & $\begin{array}{l}12.56 \\
(3.95)^{\mathrm{ab}}\end{array}$ & $\begin{array}{l}13.15 \\
(2.82)^{\mathrm{a}}\end{array}$ \\
\hline & $\mathrm{D}$ & $\begin{array}{l}15.59 \\
(3.55)^{b}\end{array}$ & $\begin{array}{l}23.66 \\
(5.89)^{a}\end{array}$ & $\begin{array}{l}18.51 \\
(7.70)^{\mathrm{ab}}\end{array}$ & $\begin{array}{l}20.26 \\
(5.55)^{\mathrm{ab}}\end{array}$ & $\begin{array}{l}14.97 \\
(6.45)^{\mathrm{b}}\end{array}$ & $\begin{array}{l}17.40 \\
(6.18)^{\mathrm{ab}}\end{array}$ & $\begin{array}{l}20.97 \\
(6.99)^{\mathrm{ab}}\end{array}$ & $\begin{array}{l}25.66 \\
(6.18)^{\mathrm{a}}\end{array}$ \\
\hline \multirow[t]{2}{*}{ ER } & $\mathrm{E}$ & $\begin{array}{l}15.52 \\
(3.34)^{\mathrm{ab}}\end{array}$ & $\begin{array}{l}11.49 \\
(5.52)^{\mathrm{b}}\end{array}$ & $\begin{array}{l}13.80 \\
(5.82)^{\mathrm{ab}}\end{array}$ & $\begin{array}{l}15.63 \\
(4.03)^{\mathrm{ab}}\end{array}$ & $\begin{array}{l}17.73 \\
(4.55)^{\mathrm{a}}\end{array}$ & $\begin{array}{l}13.72 \\
(6.91)^{\mathrm{ab}}\end{array}$ & $\begin{array}{l}17.13 \\
(5.19)^{\mathrm{a}}\end{array}$ & $\begin{array}{l}17.66 \\
(5.17)^{\mathrm{a}}\end{array}$ \\
\hline & $\mathrm{D}$ & $\begin{array}{l}13.42 \\
(4.22)^{\mathrm{bc}}\end{array}$ & $\begin{array}{l}7.52 \\
(7.63)^{c}\end{array}$ & $\begin{array}{l}13.20 \\
(8.33)^{\mathrm{bc}}\end{array}$ & $\begin{array}{l}16.34 \\
(5.97)^{\mathrm{ab}}\end{array}$ & $\begin{array}{l}15.92 \\
(9.77)^{\mathrm{ab}}\end{array}$ & $\begin{array}{l}11.16 \\
(7.87)^{\mathrm{bc}}\end{array}$ & $\begin{array}{l}21.16 \\
(6.75)^{\mathrm{ab}}\end{array}$ & $\begin{array}{l}22.79 \\
(4.59)^{\mathrm{a}}\end{array}$ \\
\hline
\end{tabular}

Abbreviations: D, dentin; E, enamel; ER, etch-and-rinse; SE, self-etch; SH1h, NaOCl storage for 1 hour; SH5h, NaOCl storage for 5 hours; T10,000, thermocycling in 10,000; T20,000, thermocycling in 20,000; T30,000, thermocycling in 30,000; W24h, water storage at $37^{\circ} \mathrm{C}$ for 24 hours; W6m, water storage at $37^{\circ} \mathrm{C}$ for 6 months; $W 12 \mathrm{~m}$, storage at $37^{\circ} \mathrm{C}$ for 12 months.

Notes: Different lowercase letter in lines indicate statistical significant differences by three-way analysis of variance and Bonferroni post hoc tests $(\alpha=0.05)$. As the "adhesive approach" factor proved not to be statistically significant, Bonferroni post hoc tests for such factor were omitted.

Table 4 Weibull analysis-modulus, confidence intervals, and statistical significance

\begin{tabular}{|c|c|c|c|c|c|c|c|c|c|}
\hline $\begin{array}{l}\text { Adhesive } \\
\text { approach }\end{array}$ & Substrate & W24 h & W6 m & W12 m & $\mathrm{T} 10,000$ & $\mathrm{~T} 20,000$ & T30,000 & SH1 h & SH5 h \\
\hline \multirow[t]{2}{*}{ SE } & E & $\begin{array}{l}3.80 \\
(2.58-5.61)^{\mathrm{ab}}\end{array}$ & \begin{tabular}{|l|}
3.96 \\
$(2.77-5.68)^{\mathrm{ab}}$
\end{tabular} & $\begin{array}{l}2.25 \\
(1.55-3.26)^{\mathrm{a}}\end{array}$ & $\begin{array}{l}4.63 \\
(3.13-6.86)^{\mathrm{ab}}\end{array}$ & \begin{tabular}{|l|}
3.11 \\
$(2.14-4.52)^{\mathrm{ab}}$
\end{tabular} & $\begin{array}{l}3.47 \\
(2.42-4.91)^{\mathrm{ab}}\end{array}$ & $\begin{array}{l}3.45 \\
(2.46-4.85)^{\mathrm{ab}}\end{array}$ & $\begin{array}{l}5.32 \\
(3.76-7.51)^{b}\end{array}$ \\
\hline & $\mathrm{D}$ & $\begin{array}{l}4.51 \\
(3.24-6.28)^{a}\end{array}$ & $\begin{array}{l}4.45 \\
(3.15-6.28)^{a}\end{array}$ & \begin{tabular}{|l}
3.58 \\
$(2.47-5.17)^{\mathrm{a}}$
\end{tabular} & \begin{tabular}{|l}
4.05 \\
$(2.86-5.73)^{\mathrm{a}}$
\end{tabular} & \begin{tabular}{|l}
3.14 \\
$(2.15-4.59)^{a}$
\end{tabular} & $\begin{array}{l}3.21 \\
(2.23-4.63)^{a}\end{array}$ & \begin{tabular}{|l|}
3.33 \\
$(2.25-4.91)^{\mathrm{a}}$
\end{tabular} & \begin{tabular}{|l}
4.68 \\
$(3.29-6.64)^{a}$
\end{tabular} \\
\hline \multirow[t]{2}{*}{ ER } & $E$ & $\begin{array}{l}5.48 \\
(3.79-7.93)^{b}\end{array}$ & $\begin{array}{l}2.29 \\
(1.62-3.25)^{\mathrm{a}}\end{array}$ & $\begin{array}{l}2.70 \\
(1.85-3.94)^{\mathrm{ab}}\end{array}$ & $\begin{array}{l}4.77 \\
(3.28-6.92)^{b}\end{array}$ & $\begin{array}{l}4.17 \\
(2.98-5.82)^{\mathrm{ab}}\end{array}$ & \begin{tabular}{|l|}
3.64 \\
$(2.51-5.28)^{\mathrm{ab}}$
\end{tabular} & $\begin{array}{l}3.82 \\
(2.65-5.51)^{\mathrm{ab}}\end{array}$ & $\begin{array}{l}4.20 \\
(2.85-6.17)^{\mathrm{ab}}\end{array}$ \\
\hline & D & \begin{tabular}{|l|}
3.70 \\
$(2.56-5.33)^{\mathrm{ab}}$
\end{tabular} & $\begin{array}{l}1.94 \\
(1.27-2.74)^{\mathrm{a}}\end{array}$ & \begin{tabular}{|l|}
3.08 \\
$(2.12-4.46)^{\mathrm{ab}}$
\end{tabular} & \begin{tabular}{|l}
3.06 \\
$(2.13-4.39)^{\mathrm{ab}}$
\end{tabular} & \begin{tabular}{|l|}
1.84 \\
$(1.25-2.71)^{\mathrm{a}}$
\end{tabular} & \begin{tabular}{|l|}
2.44 \\
$(1.71-3.47)^{\mathrm{a}}$
\end{tabular} & \begin{tabular}{|l|}
3.76 \\
$(2.57-5.51)^{\mathrm{ab}}$
\end{tabular} & \begin{tabular}{|l}
5.42 \\
$(3.83-7.68)^{b}$
\end{tabular} \\
\hline
\end{tabular}

Abbreviations: D, dentin; E, enamel; ER, etch-and-rinse; SE, self-etch; SH1h, NaOCl storage for 1 hour; SH5h, NaOCl storage for 5 hours; T10,000, thermocycling in 10,000; T20,000, thermocycling in 20,000; T30,000, thermocycling in 30,000; W24h, water storage at $37^{\circ} \mathrm{C}$ for 24 hours; W6m, water storage at $37^{\circ} \mathrm{C}$ for 6 months; $W 12 \mathrm{~m}$, storage at $37^{\circ} \mathrm{C}$ for 12 months.

Note: Different lowercase letter in lines indicate statistical significant differences depicted by maximum likelihood estimation via Weibull analysis (absence of overlap of $95 \%$ confidence intervals).

results in both substrates, since the confidence interval was higher than the other aging methods.

Adhesive/mixed failures were predominant for all groups, regardless of the substrate, adhesive, or aging methods ( - Table 5).

\section{Discussion}

This study focused on testing and comparing the effects of different aging methods on the bond strength of a universal adhesive using SE and ER approaches to dentin and enamel substrates. In vitro studies of bond stability associated with aging methods may be considered more reliable to predict adhesive performance. Despite this, it is suggested that the mechanism of bond degradation observed in laboratory techniques may not be applied at the same rate clinically and the bond strength has a secondary role in the clinical success of bonded restorations. ${ }^{24}$

The null hypothesis was rejected, since the different aging methods studied affected the bond strength independently of the adhesive approach and substrate.

\section{Water Storage}

The most frequent aging method related in the literature is the storage in distilled water under room temperature or $37^{\circ} \mathrm{C}$, since this method has been generally accepted as a way to predict the time in which an adhesive interface would remain stable.,12,13 Studies performed with water storage indicate that degradation was accelerated by hydrolysis of the hydrophilic resin components and by host-derived proteases with collagenolytic activity. ${ }^{4}$

Storage for 6 months using the ER approach reduced the bond strength more than storage in hypochlorite and 20,000 thermal cycles, suggesting that this method is more effective when using this approach. This also leads us to believe that the SE approach is more resistant to this aging, since the bond strength in this and other studies with universal adhesives remains stable, even after 1 year of water storage. ${ }^{13,25}$

According to Scherrer et al, ${ }^{11}$ the behavior of these adhesives bonded to dentin is better evaluated using the Weibull distribution function, predicting the likelihood of failure at specific stress levels in which Weibull $m$ reports the variability of the results. The highest $m$ value was reached in enamel and the lowest was in the dentin group, both with the ER approach after 24 hours.

Regional variability of dentin tissue and more recently chemical bonding component of dental adhesives was added to bond strength studies. ${ }^{26,27}$ It was observed that contemporary adhesives follow the tendency of having the 10-methacryloyldecyl dihydrogen phosphate (MDP) in their formulation 

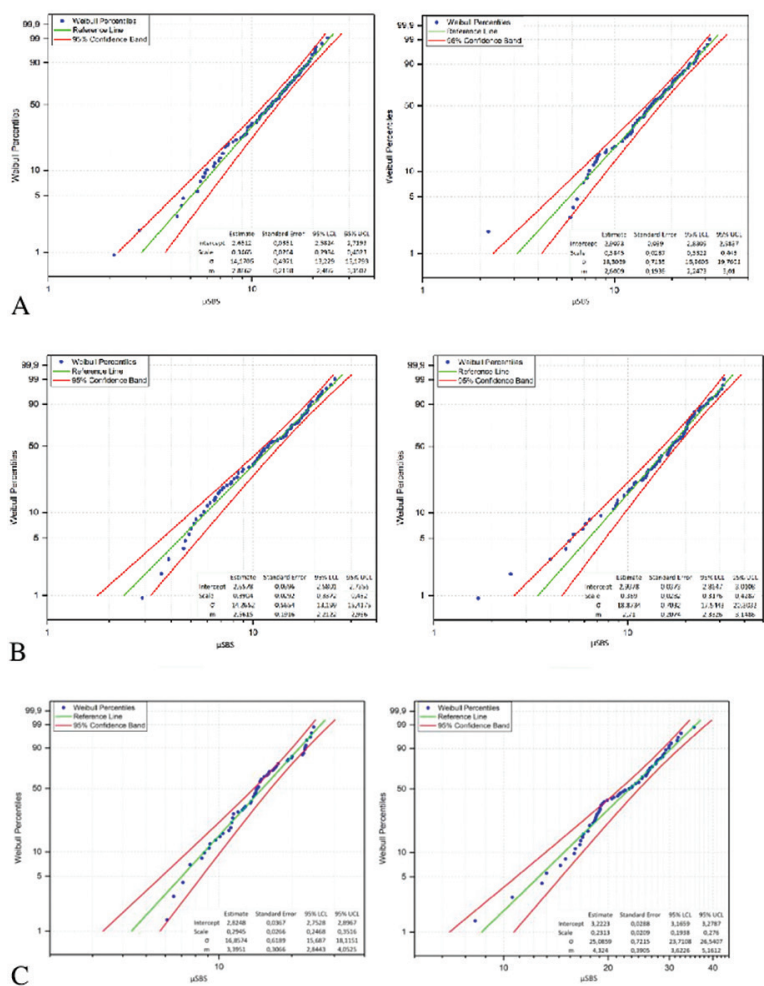

Fig. 1 Probability plot with Weibull curves at maximum likelihood estimation. Estimate scale $(\sigma)$ and shape $(m)$ values with standard error and lower confidence level (LCL) and upper confidence level (UCL). The confidence interval $(95 \% \mathrm{Cl})$ is the band between $\mathrm{LCL}$ and UCL. (A) Groups aged in water for 24 hours, 6 months, and 12 months (self-etching and etch-and-rinse), enamel and dentin, respectively. (B) Groups thermocycled 10,000, 20,000, and 30,000 times (self-etching and etch-and-rinse), enamel and dentin, respectively. (C) Groups aged in sodium hypochlorite, 1 and 5 hours (self-etching and etch-and-rinse), enamel and dentin, respectively.

Table 5 Failure mode

\begin{tabular}{|l|l|l|l|l|}
\hline \multirow{2}{*}{ Groups } & \multicolumn{5}{|c|}{ Failure mode (\%) } \\
\cline { 2 - 5 } & $\begin{array}{l}\text { Adhesive/ } \\
\text { mixed }\end{array}$ & $\begin{array}{l}\text { Cohesive } \\
\text { in enamel }\end{array}$ & $\begin{array}{l}\text { Cohesive } \\
\text { in dentin }\end{array}$ & $\begin{array}{l}\text { Cohesive } \\
\text { in resin }\end{array}$ \\
\hline $\begin{array}{l}\text { Control } \\
\text { (W24 h) }\end{array}$ & $100 \%$ & - & - & - \\
\hline $\mathrm{W}$ & $80 \%$ & $5 \%$ & $15 \%$ & - \\
\hline $\mathrm{T}$ & $86 \%$ & $4 \%$ & $10 \%$ & - \\
\hline $\mathrm{SH}$ & $100 \%$ & - & - & - \\
\hline
\end{tabular}

as a functional monomer. ${ }^{28}$ The obtained results in the W24, $\mathrm{W} 6 \mathrm{~m}$, and $\mathrm{W} 12 \mathrm{~m}$ groups onto the dentin substrate using the SE approach revealed that $\mathrm{W} 6 \mathrm{~m}$ showed an unexpected increase of bond strength comparing with the baseline (W24h), which is in accordance with Kawazu et al (2020). ${ }^{8}$ These results can be explained by the composition of adhesive that contains 10 to $15 \%$ water which helps ionize the functional resin monomer. $^{29}$ The Weibull analysis presented no relevancy since these groups reached $m$ values of 4.51 (W24h), 4.45 (W6m), and $3.58(\mathrm{~W} 12 \mathrm{~m})$. Therefore, it can be assumed that the cited groups showed a regular distribution of defects.

\section{Thermocycling}

Research protocols conclude that 500 cycles through water baths at 5 and $55^{\circ} \mathrm{C}$, as preconized by ISO TR $11450^{30}$ is very limited to promote effects on bond strength and/or microleakage of the adhesive interface. ${ }^{15,31}$ Therefore, the studies arbitrarily determine the number of thermocycles, accepting that 10,000 thermocycles correspond to 1 year of in vivo degradation..$^{14}$

Based on this information, this study performed the equivalent of 3 years of clinical use (T30,000) of Scotchbond Universal in both strategies, which may be considered as a reasonable aging time. Under the SE approach, the values for dentin after thermocycling were generally higher for bond strength than enamel. Nevertheless, corroborating a study by Hariri et $\mathrm{al}^{13}$ the aging with thermocycling presented more predictable enamel results than is sustained by the Weibull analysis, since the shape, $m$, and confidence interval values were adequately distributed. The 20,000 and 30,000 cycles of the enamel group using SE approach presented significantly lower results than the baseline, contradicting other studies, 25,32 which could be explained by the use of other bond strength tests and substrate.

\section{Storage in $10 \% \mathrm{NaOCl}$}

It is known that for clinical uses, the concentration of $\mathrm{NaOCl}$ is lower than $10 \%$. In this study, the $10 \% \mathrm{NaOCl}$ solution is considered an extreme condition of aging, and it was used according to the previous studies ${ }^{10,33,34}$ as a guarantee of the organic component of dentin been degraded. This study showed that the storage in $10 \% \mathrm{NaOCl}$ solution did not reduce the bond strength for any time tested. Other studies which stated lower bond strength had used the same concentration of the $\mathrm{NaOCl}$ solution but different adhesives and bond strength testing. ${ }^{10,33,34}$ On the contrary, the $m$ showed higher values in dentin with the ER approach in the SH5h group, indicating lower variability (meaning lower spread) in bond strength, which means a high reliability of the characteristic bond strength and probable absence of critical flaws. ${ }^{11}$ This may also have been the influence of incorporating the 10-MDP monomer in the adhesive, increasing the SE capability and higher chemical stability and the presence of polyalkenoic acid copolymer, ${ }^{35,36}$ which may explain the better results for bond strength. ${ }^{37}$

The aging methods focused on this study influenced the bond strength to Scotchbond Universal as the adhesive system. These findings support that bond strength remains stable under some artificial aging methods. However, this is an in vitro study, so further clinical trials are needed to better understand the behavior of bonded restorations using other adhesives.

\section{Conclusion}

Thermocycling prove to be the method, which promoted the most intense degradation of bond interface and induced the lowest bond strength (especially at 20,000 or 30,000 cycles). 
On the contrary, storage with $\mathrm{NaOCl}$ method proved to increase the bond strength in the evaluated conditions.

\section{Funding}

This study was funded by the Brazilian Federal Agency for Coordination of Improvement of Higher Education Personnel-CAPES (Finance Code 001).

\section{Conflict of Interest}

None declared.

\section{References}

1 De Munck J, Van Landuyt K, Peumans M, et al. A critical review of the durability of adhesion to tooth tissue: methods and results. J Dent Res 2005;84(2):118-132

2 Borgo GO, Vieira-Junior WF, Theobaldo JD, Aguiar FHB, Lima DANL. Effect of dentin pretreatment with arginine on microshear bond strength of etch-and-rinse or self-etch adhesive systems. Eur J Dent 2019;13(2):199-205

3 Fukuoka A, Koshiro K, Inoue S, et al. Hydrolytic stability of one-step self-etching adhesives bonded to dentin. J Adhes Dent 2011;13(3):243-248

4 Frassetto A, Breschi L, Turco G, et al. Mechanisms of degradation of the hybrid layer in adhesive dentistry and therapeutic agents to improve bond durability-a literature review. Dent Mater 2016;32(2):e41-e53

5 Hanabusa M, Mine A, Kuboki T, et al. Bonding effectiveness of a new 'multi-mode' adhesive to enamel and dentine. J Dent 2012;40(6):475-484

6 Matos AB, Trevelin LT, da Silva BTF, Francisconi-Dos-Rios LF, Siriani LK, Cardoso MV. Bonding efficiency and durability: current possibilities. Braz Oral Res 2017;31(Suppl 1) :e57

7 Cardoso MV, de Almeida Neves A, Mine A, et al. Current aspects on bonding effectiveness and stability in adhesive dentistry. Aust Dent J 2011;56(1,suppl 1) :31-44

8 Kawazu M, Takamizawa T, Hirokane E, et al. Comparison of dentin bond durability of a universal adhesive and two etch-and-rinse adhesive systems. Clin Oral Investig 2020; 24(8):2889-2897

9 De Munck J, Ermis RB, Koshiro K, et al. NaOCl degradation of a HEMA-free all-in-one adhesive bonded to enamel and dentin following two air-blowing techniques. J Dent 2007; 35(1):74-83

10 Deng D, Yang H, Guo J, Chen X, Zhang W, Huang C. Effects of different artificial ageing methods on the degradation of adhesive-dentine interfaces. J Dent 2014;42(12):1577-1585

11 Scherrer SS, Cesar PF, Swain MV. Direct comparison of the bond strength results of the different test methods: a critical literature review. Dent Mater 2010;26(2):e78-e93

12 Nagarkar S, Theis-Mahon N, Perdigão J. Universal dental adhesives: current status, laboratory testing, and clinical performance. J Biomed Mater Res B Appl Biomater 2019;107(6): 2121-2131

13 Suzuki S, Takamizawa T, Imai A, et al. Bond durability of universal adhesive to bovine enamel using self-etch mode. Clin Oral Investig 2018;22(3):1113-1122

14 Gale MS, Darvell BW. Thermal cycling procedures for laboratory testing of dental restorations. J Dent 1999;27(2):89-99

15 Amaral FL, Colucci V, Palma-Dibb RG, Corona SA. Assessment of in vitro methods used to promote adhesive interface degradation: a critical review.J Esthet Restor Dent 2007;19(6):340-353, discussion 354

16 Mobarak EH, El-Badrawy W, Pashley DH, Jamjoom H. Effect of pretest storage conditions of extracted teeth on their dentin bond strengths. J Prosthet Dent 2010;104(2):92-97
17 TayFR,Pashley DH.Aggressiveness of contemporary self-etching systems. I: Depth of penetration beyond dentin smear layers. Dent Mater 2001;17(4):296-308

18 Tedesco TK, Montagner AF, Skupien JA, Soares FZ, Susin AH, Rocha RO. Starch tubing: an alternative method to build up microshear bond test specimens. J Adhes Dent 2013; 15(4):311-315

19 Foong J, Lee K, Nguyen C, et al. Comparison of microshear bond strengths of four self-etching bonding systems to enamel using two test methods. Aust Dent J 2006;51(3):252-257

20 Davies D. A statistical approach to engineering design in ceramics. Proc Br Ceram Soc. 1973;22:429-452

21 Stanley P, Fessler H, Siviil A. An engineer's approach to the prediction of failure probability of brittle components. Proc $\mathrm{Br}$ Ceram Soc. 1973;22:453-487

22 Burrow MF, Thomas D, Swain MV, Tyas MJ. Analysis of tensile bond strengths using Weibull statistics. Biomaterials 2004;25(20):5031-5035

23 McCabe JF, Walls AW. The treatment of results for tensile bond strength testing. J Dent 1986;14(4):165-168

24 Carvalho RM, Manso AP, Geraldeli S, Tay FR, Pashley DH. Durability of bonds and clinical success of adhesive restorations. Dent Mater 2012;28(1):72-86

25 Sai K, Shimamura Y, Takamizawa T, et al. Influence of degradation conditions on dentin bonding durability of three universal adhesives. J Dent 2016;54:56-61

26 De Munck J, Mine A, Vivan Cardoso M, et al. Effect of dentin location and long-term water storage on bonding effectiveness of dentin adhesives. Dent Mater J 2011;30(1):7-13

27 Pashley DH, Ciucchi B, Sano H, Carvalho RM, Russell CM. Bond strength versus dentine structure: a modelling approach. Arch Oral Biol 1995;40(12):1109-1118

28 Tsuchiya K, Takamizawa T, Barkmeier WW, et al. Effect of a functional monomer (MDP) on the enamel bond durability of single-step self-etch adhesives. Eur J Oral Sci 2016;124(1):96-102

29 Moszner N, Salz U, Zimmermann J. Chemical aspects of self-etching enamel-dentin adhesives: a systematic review. Dent Mater 2005;21(10):895-910

30 ISO TR 11450. Dental Materials - Guidance on testing of adhesion to tooth structure. Geneva, Switzerland: International Organization for Standardization; 1994: 1-14

31 Hariri I, Shimada Y, Sadr A, Ichinose S, Tagami J. The effects of aging on shear bond strength and nanoleakage expression of an etch-and-rinse adhesive on human enamel and dentin. J Adhes Dent 2012;14(3):235-243

32 Wagner A, Wendler M, Petschelt A, Belli R, Lohbauer U. Bonding performance of universal adhesives in different etching modes. J Dent 2014;42(7):800-807

33 Gan J, Liu S, Zhou L, Wang Y, Guo J, Huang C. Effect of Nd:YAG laser irradiation pretreatment on the long-term bond strength of etch-and-rinse adhesive to dentin. Oper Dent 2017; 42(1):62-72

34 Nima G, Cavalli V, Bacelar-Sá R, Ambrosano GMB, Giannini M. Effects of sodium hypochlorite as dentin deproteinizing agent and aging media on bond strength of two conventional adhesives. Microsc Res Tech 2020;83(2):186-195

35 Muñoz MA, Luque-Martinez I, Malaquias P, et al. In vitro longevity of bonding properties of universal adhesives to dentin. Oper Dent 2015;40(3):282-292

36 Perdigão J, Kose C, Mena-Serrano AP, et al. A new universal simplified adhesive: 18-month clinical evaluation. Oper Dent 2014;39(2):113-127

37 Yoshida Y, Yoshihara K, Nagaoka N, et al. Self-assembled Nanolayering at the adhesive interface. J Dent Res 2012;91(4): 376-381 